\title{
PENGEMBANGAN GAMELAN JEGOG SEBAGAI DAYA TARIK WISATA DI KABUPATEN JEMBRANA
}

\author{
I Komang Edy Wirawan \\ Prodi Magister Kajian Pariwisata Universitas Udayana \\ Email: ikomang_edy@yahoo.com \\ N.L. Sutjiati Beratha \\ Fakultas IImu Budaya Universitas Udayana \\ Email: sutjiati59@gmail.com
}

\begin{abstract}
Jembrana have a number of cultural potentials that can be developed as tourist attractions, one of which is the art of gamelan jegog musical instrument. Gamelan jegog made of bamboo and produce a beautiful tone. This study aims to identify the potential and constraints gamelan jegog as a tourist attraction, and to formulate an effective development strategy to be implemented. Data collection techniques used in this study were the observation, structured interviews with 11 informants from the community and the government that has insights of gamelan jegog. The method used is descriptive-qualitative and SWOT analysis. The results showed that the gamelan jegog potential can be developed into a tourist attraction in Jembrana by minimizing the constraints owned. Through SWOT approach then obtained jegog gamelan development strategy in the form of SO (strength-opportunities) strategy, namely the development of tourism potential in the district of Jembrana and increase cooperation and utilization of technology.
\end{abstract}

Keywords: Development, Tourist Attractions, Gamelan Jegog

\section{Pendahuluan}

Kabupaten Jembrana adalah kabupaten yang terletak di barat pulau Bali yang memiliki potensi daya tarik wisata. Menurut Yoeti (2006:55) daya tarik wisata dapat dibagi menjadi empat bagian sebagai berikut; (1) daya tarik wisata alam, (2) daya tarik wisata dalam bentuk bangunan, (3) daya tarik wisata budaya, (4) daya tarik wisata sosial. Daya tarik wisata budaya yang menjadi andalan dari Kabupaten Jembrana adalah gamelan jegog.

Gamelan jegog telah berkembang di Kabupaten Jembrana sejak tahun 
1912. Hampir diseluruh desa/kelurahan di Kabupaten Jembrana memiliki jegog sebagai hiburan masyarakat. Tahun 1989 Kelurahan Sangkaragung merupakan kelurahan yang pertama mengemas pertunjukan gamelan jegog sebagai daya tarik wisata. Hal ini ditandai dengan dibentuknya suatu yayasan yang bergerak dibidang kebudayaan dan pariwisata yang bernama Yayayasan Suar Agung. Yayasan Suar Agung telah memperoleh izin dari Pemerintah Daerah Tingkat I Bali dan Pemerintah Daerah Tingkat II Jembrana dengan Akta Notaris No. 10 tanggal 4 September 1989. Pembentukan Yayasan Suar Agung bertujuan untuk mempromosikan gamelan jegog dan menjadikan jegog sebagai daya tarik wisata di Kabupaten Jembrana.

Sejak dibentuk, gamelan jegog Yayasan Suar Agung berkembang dengan baik. Eksistensi gamelan jegog Suar Agung sebagai daya tarik wisata semakin terlihat dari upaya Yayasan Suar Agung untuk menyiapkan panggung pementasan gamelan jegog. Panggung pementasan yang dikelola langsung oleh Yayasan Suar Agung dibuat secara profesional dengan konsep terbuka, sehingga memberikan kesan mewah pada setiap pertunjukan gamelan jegog.

Namun dalam perkembangannya, gamelan jegog suar agung belum mampu menjadi daya tarik wisata unggulan di Kabupaten Jembrana yang dapat dinikmati oleh wisatawan. Hal ini bisa dilihat dari adanya programprogram Yayasan Suar Agung yang tidak dapat terlaksana. Salah satu program dari Yayasan Suar Agung adalah pementasan yang dilaksanakan setiap hari kamis dan sabtu pada tiap minggunya. Namun dalam pelaksanaannya hanya pada bulan-bulan tertentu (Mei-Juli) program tersebut dapat terlaksana, mengingat jumlah kunjungan yang kurang mengakibatkan tidak berjalannya program tersebut. Hal ini tentu bertentangan dengan tujuan pembentukan Yayasan Suar Agung.

Artikel ini akan menganalisis potensi dari jegog Yayasan Suar Agung dengan melihat kendala-kendala yang dihadapi jegog, serta dapat memberikan strategi pengembangan dan juga strategi alternatif gamelan jegog Suar Agung sehingga dapat diterapkan gamelan jegog guna manjadi daya tarik wisata di Kabupaten Jembrana.

\section{Teori dan Metode}

Teori yang digunakan dalam artikel ini adalah teori perencanaan. Menurut Paturusi (2008:28) suatu perencanaan memiliki dua syarat utama yaitu. (1) Logis yaitu bisa dimengerti dan sesuai dengan kenyataan yang berlaku, luwes yaitu dapat mengikuti perkembangan. (2) Obyektif yaitu didasarkan pada tujuan dan sasaran yang dilandasi pertimbangan yang sistematis dan ilmiah. Dengan demikian akan diketahui perencanaan yang layak diterapkan untuk pengembangan gamelan jegog sebagai daya tarik wisata. Potensi yang ada akan dapat dikembangkan dengan suatu perencanaan yang baik, sehingga kedepannya dapat dirumuskan suatu strategi yang tepat untuk diterapkan 
kedalam strategi pengembangan gamelan jegog sebagai daya tarik wisata di Kabupaten Jembrana.

Metode penelitian yang digunakan adalah metode penelitian kualitatif, dengan teknik pengumpulan data dilakukan dengan observasi, wawancara mendalam, dan dokumentasi. Wawancara mendalam dibantu dengan pedoman wawancara dilakukan dengan memilih informan menggunakan metode porposive sampling. Informan dalam penelitian ini adalah ketua dan wakil ketua Yayasan Suar Agung (2 orang), kepala Kelurahan Sangkaragung (1 orang), masyarakat (5 orang) dan Dinas Pendidikan, Pemuda Olahraga, Pariwisata dan Kebudayaan Kabupaten Jembrana (3 orang). Informan akan diberikan pertanyaan terkait dengan jegog Yayasan Suar Agung mengunakan pedoman wawancara terstruktur dan bersifat terbuka, artinya setiap pertanyaan dapat terus berkembang seiring dengan jawaban yang didapatkan.

Selanjutnya akan dianalisis melalui pendekatan SWOT, dengan menggali informasi untuk mengetahui potensi, kendala, kekuatan, kelemahan, peluang, dan tantangan serta rencana strategi pengembangan Yayasan Suar Agung sebagai daya tarik wisata di Kabupaten Jembrana (Rangkuti, 2006:19).

\section{Potensi dan Kendala Panggung Pementasan Jegog sebagai Daya Tarik Wisata}

Potensi adalah kemapuan yang mempuanyai kemungkinan untuk dikembangkan sedangkan kendala merupakan suatu keadaan yang membatasi, menghalangi, atau mencegah pencapaian sasaran. Berikut akan dijelaskan potensi panggung pementasan jegog serta kendalanya sebagai daya tarik wisata di Kabupaten Jembrana.

\subsection{Potensi Panggung Pementasan Jegog sebagai Daya Tarik Wisata}

Potensi panggung pementasan Gamelan Jegog Yayasan Suar Agung dianalisis melalui pendekatan 4A (Attraction, Accessibility, Amenities, Ancillary service) Suwena (2010:85). Berdasarkan komponen destinasi pariwisata tersebut akan diuraikan potensi dari gamelan jegog di Kabupaten Jembrana.

Pertama, potensi dari atraksi gamelan jegog adalah (a). Jegog mebarung yaitu pertarungan dua sampai dengan tiga perangkat gamelan jegog yang dilakukan dengan memainkan gamelan jegog secara bersamaan tanpa berhenti, dan kemenangan akan didapatkan dari gamelan jegog yang paling lama bertahan (b). Kolaborasi dengan musik modern, telah berkembang dari tahun 1995 dengan memadukan musik dari gamelan jegog dengan berbagai jenis musik modern dan juga musik tradisional (Lihat Foto 1). (c). Jegog 


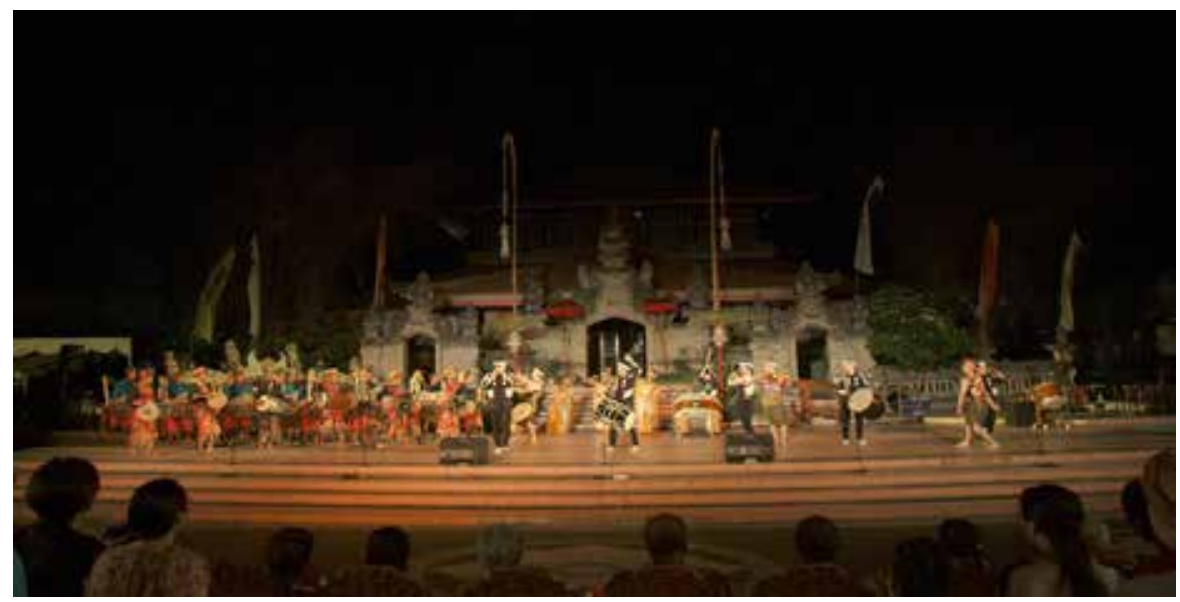

Foto 1. Kolaborasi jegog dengan musik tradisional Jepang (Kodo) di Institut Seni Indonesia (ISI) Denpasar.

sebagai media pengobatan merupakan potensi yang dapat dikembangkan yaitu terapi dengan cara memainkan salah satu intrumen gamelan jegog yang disebut kancilan (instrument dalam gamelan jegog sebagai pengatur irama) dilakukan selama 30 menit terapi selama 4 kali dalam sebulan. Tercatat dalam lima tahun terakhir (2010-2015) terdapat 2 wisatawan yang telah melakukan terapi dengan media musik dari gamelan jegog.

Kedua, dilihat dari aksesibilitas tempat pementasan gamelan jegog berada di Kelurahan Sangkaragung, Kabupaten Jembrana yang kurang lebih menempuh jarak $100 \mathrm{~km}$ dari Nusa Dua dan Kuta. Selain itu, gamelan jegog telah mengadakan kerjasama dengan restoran untuk mempermudah akses wisatawan yang hendak menikmati pementasan gamelan jegog, namun selalu dianjurkan kepada wisatawan untuk langsung melihat pertunjukan gamelan jegog di Kelurahan Sangkaragung. Gamelan jegog Suar Agung memiliki website resmi yaitu www.jegogsuaragung.com yang menjadi media yang digunakan oleh pengelola yayasan untuk dapat diakses oleh wisatawan. Di dalamnya terdapat menu home, bio, store, photo gallery, reviews sampai dengan menu pemesanan untuk wisatawan.

Ketiga, amenities (Fasilitas penunjang) pariwisata yang terdapat di kelurahan sangkaragung yaitu berupa tempat pementasan yang memiliki luas $400 \mathrm{~m}^{2} / 4$ are dengan kapasitas penonton mencapai 50 wisatawan duduk atau 200 wisatawan berdiri. Selain itu juga untuk pendistribusian wisatawan yang menginap ke Kelurahan Sangkaragung disebar dirumahrumah warga yang diubah menjadi penginapan dengan konsep homestay. Terdapat sekitar 10 homestay yag tersebar di Kelurahan Sangkaragung 


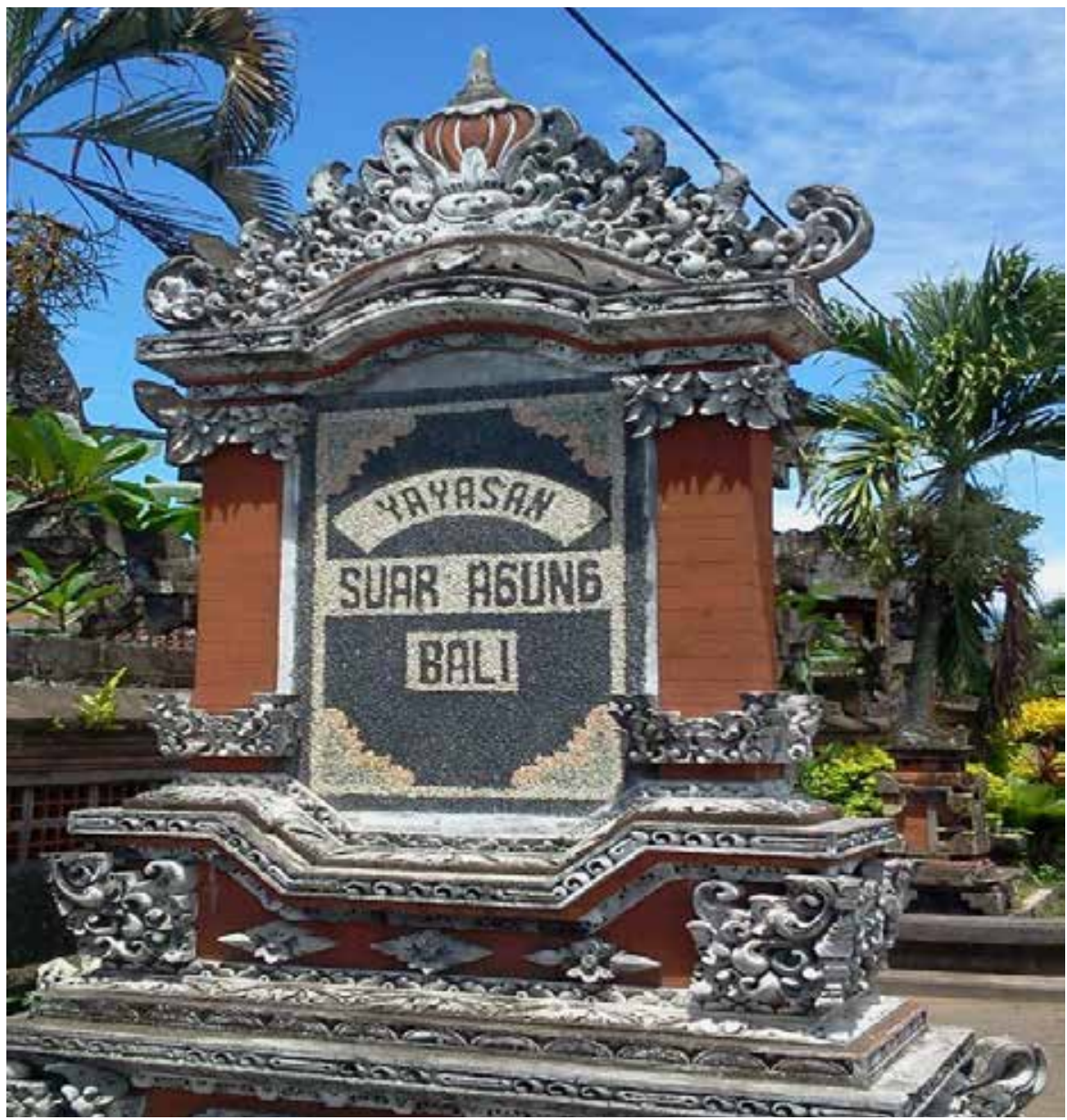

Foto 2 Yayasan Suar Agung Kabupaten Jembrana

Keempat, ancilary service (kelembagaan) yang terdapat di Kelurahan Sangkaragung yang langsung menyentuh gamelan jegog adalah Yayasan Suar Agung yang diketuai oleh I Ketut Suwentra yang sepenuhnya bertanggung jawab pada setiap kerjasama yang dilakukan. Yayasan Suar Agung juga memfasilitasi masyarakat yang ingin belajar menabuh maupun menari. Masyarakat dapat langsung terlibat di dalamnya sehingga langsung mengetahui perkembangan tentang gamelan jegog. Selain itu juga manfaat ekonomi bagi masyarakat akan menjadi nilai tambah dari keberadaan Yayasan Suar Agung (Foto 2).

\subsection{Kendala Panggung Pementasan Jegog sebagai Daya Tarik Wisata}

Selain dari keempat potensi yang dimiliki gamelan jegog terdapat pula kendala dalam pengembangannya. Terdapat tiga kendala utama dalam 


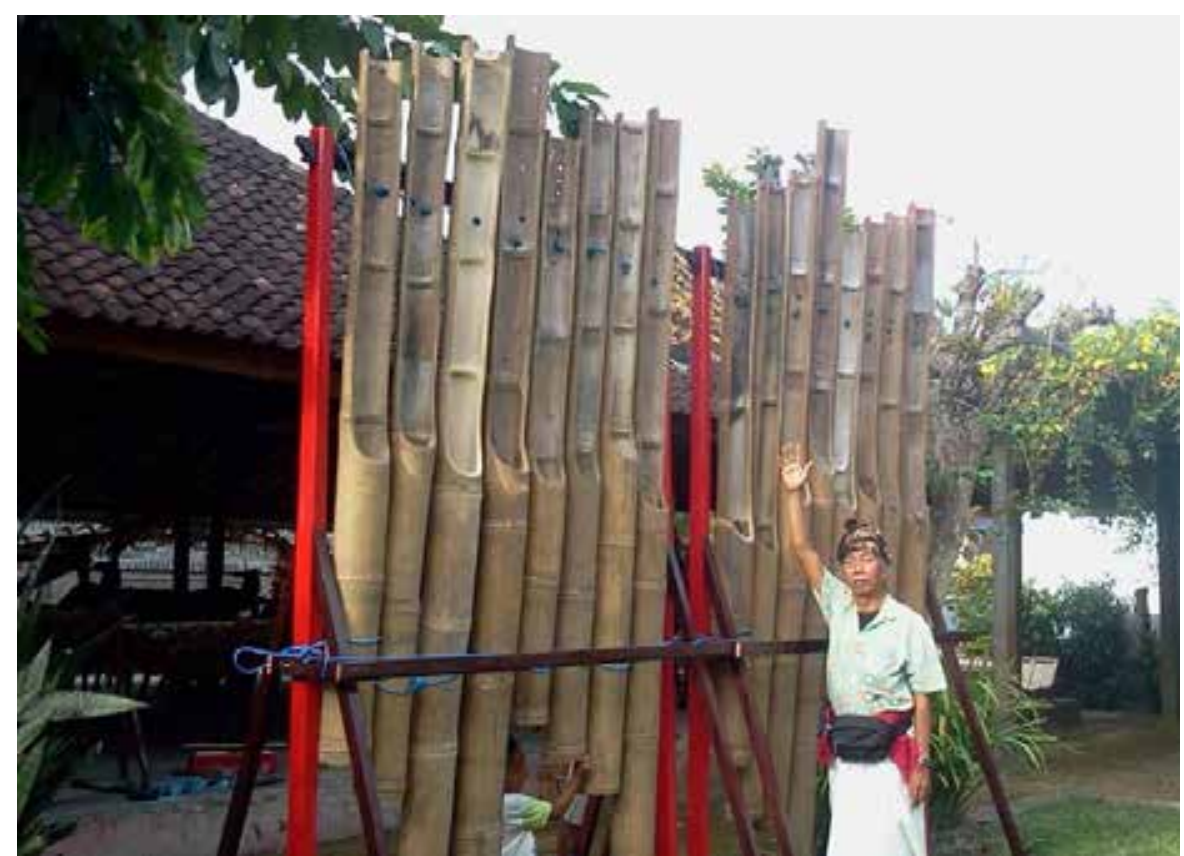

Foto 3. I Ketut Suwentra berfoto dengan gamelan jegog di Yayasan Suar Agung Kelurahan Sangkaragung.

pengebangan gamelan jegog antara lain:

Pertama, kendala fisik yang didapatkan dari hasil analisis, observasi dan wawancara antara lain: jarak yang jauh dari ibu kota propinsi, kurangnya tanda petunjuk jalan, belum adanya daya tarik pendamping, sumber daya bambu yang makin sedikit dan tempat pementasan gamelan jegog. Kendala fisik yang terdapat pada pengembangan gamelan jegog merupakan kendala yang terkait dengan jarak, tempat dan sumber daya alam yang sangat mempengaruhi dalam pengambangan gamelan jegog kedepannya.

Kedua adalah kendala sumber daya manusia yang juga merupakan suatu kendala yang harus diantisipasi lebih cepat. Adapaun kendala sumber daya manusia antara lain; kemampuan membuat gamelan jegog, pemahaman tentang kepariwisataan, serta kemampuan dan kompentensi. Peningkatan kompetensi masyarakat tentunya dapat meningkatkan gamelan jegog sehingga dapat dikembangkan dengan baik.

Ketiga, kendala lainnya meliputi kendala yang dirasa sangat mempengaruhi gamelan jegog untuk dapat dikembangkan. Adapun kendala lainnya adalah: pengiriman gamelan jegog, dengan ukuran yang cukup besar gamelan jegog memiliki kendala dalam hal pengiriman kelokasi pementasan yang telah ditentukan. Hal ini merupaka salah satu kendala yang perlu diminimalkan dengan pengebangan gamelan jegog yang lebih mudah untuk dibawa sehingga memudahkan dalam pengiriman gamelan jegog. (Foto 3) adapun kendala lain yaitu keterbatasan dana. 


\section{Strategi Pengembangan Gamelan Jegog sebagai Daya Tarik Wisata}

Untuk menyusun suatu strategi diperlukan pendekatan SWOT (strength, weaknesses, opportunity, dan threat) dalam Pengembangan gamelan jegog. pendekatan SWOT merupakan pendekatan yang digunakan untuk menganalisis faktor internal dari gamelan jegog yang dibagi menjadi kekuatan gamelan jegog serta kelemahan gamelan jegog. Adapun faktor eksternalnya berupa peluang dan juga ancaman dari gamelan jegog.

Faktor internal dari gamelan jegog berupa kekuatan (strength) adalah; keunikan gamelan, sebagai identitas budaya di kabupaten jembrana, dan partisipasi aktif dari masyarakat lokal. Sedangkan faktor internal berupa kelemahan (weaknesses) gamelan jegog adalah; aksesibilitas tempat pementasan yang jauh, keterbatasan sumber daya alam, dan belum adanya peran Pemerintah Provinsi Bali dalam mempromosikan gamelan jegog.

Faktor eksternal dari gamelan jegog berupa peluang (opportunity) adalah; target Kementerian Pariwisata Indonesia, kerjasama dengan Jepang, dan kemajuan teknologi informasi. Sedangkan faktor eksternal gamelan jegog berupa ancaman (threat) adalah; adanya duplikasi kesenian serupa dan menurunnya kualitas pertunjukan wisata kesenian. Faktor internal dan ekternal dari gamelan jegog dapat dilihat pada Tabel 1.

Tabel 1. Matrik SWOT gamelan jegog sebagai daya tarik wisata

\begin{tabular}{|c|c|c|}
\hline Internal & Strenght / Kekuatan (S) & $\begin{array}{c}\text { Weaknesses / Kelemahan } \\
\text { (W) }\end{array}$ \\
\hline Eksternal & $\begin{array}{l}\text { 1. Keunikan gamelan } \\
\text { 2. Sebagai identitas budaya di } \\
\text { Kabupaten Jembrana } \\
\text { 3. Partisipasi masyarakat lokal }\end{array}$ & $\begin{array}{l}\text { 1. Aksesibilitas tempat pemen- } \\
\text { tasan yang jauh } \\
\text { 2. Keterbatasan sumber daya } \\
\text { alam } \\
\text { 3. Belum adanya peran Peme- } \\
\text { rintah Provinsi Bali dalam } \\
\text { mempromosikan gamelan } \\
\text { jegog }\end{array}$ \\
\hline $\begin{array}{c}\text { Opportunities / Peluang } \\
\text { (O) }\end{array}$ & Strategi S-O & Strategi W-O \\
\hline $\begin{array}{l}\text { 1. Target Kementerian Pari- } \\
\text { wisata Indonesia } \\
\text { 2. Kerjasama dengan Jepang } \\
\text { 3. Kemajuan teknologi infor- } \\
\text { masi }\end{array}$ & $\begin{array}{l}\text { 1. Pengembangan potensi } \\
\text { wisata di Kabupaten Jem- } \\
\text { brana } \\
\text { 2. Meningkatkan kerja sama } \\
\text { dan pemanfaatan teknologi }\end{array}$ & $\begin{array}{l}\text { 1. Penggalian dana dalam } \\
\text { pengembangan gamelan } \\
\text { jegog } \\
\text { 2. Peran serta Pemerintah } \\
\text { Provinsi Bali dalam promosi } \\
\text { gamelan jegog }\end{array}$ \\
\hline Threats / Ancaman (T) & Strategi S-T & Strategi W-T \\
\hline $\begin{array}{l}\text { 1. Adanya Duplikasi Kesenian } \\
\text { Serupa } \\
\text { 2. Menurunnya kualitas per- } \\
\text { tunjukan wisata kesenian }\end{array}$ & $\begin{array}{l}\text { 1. Penetapan gamelan jegog } \\
\text { sebagai warisan budaya } \\
\text { Indonesia } \\
\text { 2. Penetapan standarisasi } \\
\text { pementasan }\end{array}$ & $\begin{array}{l}\text { 1. Memperkuat Branding } \\
\text { terhadap kesenian gamelan } \\
\text { jegog } \\
\text { 2. Melakukan pembenahan } \\
\text { SDA dan SDM }\end{array}$ \\
\hline
\end{tabular}

Sumber: Hasil penelitian 2015

Berdasarkan hasil observasi dan wawancara, kekuatan gamelan jegog merupakan potensi yang dapat berkembang serta terdapat berbagai peluang 
dalam pengembangannya. Strategi SO (strength-Oportunity) merupakan startegi yang dapat diterapkan melihat dari kekuatan dan juga peluang dari gamelan jegog. berikut adalah startegi pengembangan gamelan jegog kabupaten jembrana.

\section{Strategi SO (strength-oportunity)}

(1) Pengembangan potensi wisata di Kabupaten Jembrana

Sebagai identitas budaya di Kabupaten Jembrana, gamelan jegog telah menjadi modal utama dalam promosi Kabupaten Jembrana untuk menarik wisatawan. Keunikan gamelan yang tidak dimiliki oleh kabupaten lain yang ada di Bali merupakan nilai tambah tersendiri bagi gamelan jegog. Hal ini didukung oleh rencana Kementerian Pariwisata Indonesia yang memiliki target jumlah kunjungan wisatawan mancanegara yaitu 20 juta wisatawan dan 275 juta perjalanan wisatawan domestik. Hal ini akan menjadi peluang besar bagi Kabupaten Jembrana. Pengembangan potensi wisata lainnya perlu dilakukan, guna memudahkan wisatawan untuk menikmati jembrana secara utuh tidak hanya melihat kesenian gamelan jegog. Perlu adanya pengembangan potensi wisata lain yang ada di Kabupaten Jembrana.

(2) Meningkatkan kerjasama dan pemanfaatan teknologi

Kemajuan teknologi menjadi peluang besar bagi perkembangan daerah menjadi daya tarik wisata, tidak terkecuali bagi suatu kesenian daerah. Perkembangan informasi yang cepat tersebar ke seluruh dunia melalui media sosial (facebook, twitter, path, instagram, website) merupakan peluang bagi Yayasan Suar Agung untuk mempromosikan gamelan jegog ke seluruh dunia tanpa memerlukan biaya yang tinggi. Dengan pemanfaatan teknologi serta kerjasama dengan media terkait dapat mempermudah mengenalkan gamelan jegog dan juga mengembangkannya.

\section{Strategi Alternatif Pengembangan Gamelan Jegog sebagai Daya Tarik Wisata}

Berdasarkan pendekatan analisis SWOT, selain strategi SO (strengthoportunity) terdapat tiga (3) alternatif strategi yang dapat diberikan dalam upaya pengembangan gamelan jegog. Antara lain adalah strategi WO (weaknesses-oportunity), strategi ST (strength-treath), dan Strategi WT (weaknesses-treath). Berikut ini adalah strategi-strategi pengembangan yang dapat di terapkan yang diperoleh dari analisis faktor-faktor kekuatan, kelemahan, peluang serta ancaman dari gamelan jegog. Seperti yang ditunjukkan pada Tabel 1.

\subsection{Strategi WO (weaknesses-oportunity)}

Strategi W-O merupakan strategi yang meminimalkan kelemahan untuk memanfaatkan peluang, diimplementasikan berikut ini. 
(1) Penggalian dana dalam pengembangan gamelan jegog

Dana adalah salah satu komponen penting dalam mengembangkan suatu daya tarik wisata, baik dalam perawatan maupun dalam promosi. Kerjasama yang baik dengan Pemerintah Indonesia dan Pemerintah Jepang merupakan kesempatan baik dalam mengajukan dana untuk pengembangan gamelan jegog. Yayasan Suar Agung juga dapat mengajukan proposal bagi perusahaan yang akan melakukkan CSR (corporate social responsibility). Dengan cara tersebut, Yayasan Suar Agung dapat mengajukan dana penanaman bambu sehingga sumber daya alam yang menjadi dasar pembuatan gamelan jegog dapat ditemukan di Kabupaten Jembrana.

(2) Peran serta Pemerintah Provinsi Bali dalam promosi gamelan jegog

Workshop Kementerian Pariwisata Deputi Bidang Pengembangan Kelembagaan Kepariwisataan, tanggal 16 oktober 2015 dijelaskan beberapa strategi Kementerian Pariwisata Indonesia untuk memperoleh jumlah kunjungan 20 juta wisatawan pada tahun 2019. Salah satu yang menjadi strategi adalah dana yang dikeluarkan oleh Indonesia untuk Kementerian Pariwisata di tahun 2016 adalah 5 triliun. Sekitar 60\% diperuntukkan bagi promosi dan sisanya untuk pengembangan destinasi pariwisata. Hal ini dapat dimanfaatkan oleh Provinsi Bali dalam mengajukan kesenian yang terdapat di Bali yang layak untuk dipromosikan baik di dalam maupun luar negeri oleh Kemenetrian Pariwisata Indonesia.

\subsection{Strategi ST (strength-treath)}

Merupakan strategi yang menggunakan kekuatan untuk mengatasi ancaman, adapun strateginya sebagai berikut.

(1) Penetapan gamelan jegog sebagai warisan budaya Indonesia

Kesenian gamelan jegog harus dapat diajukan untuk menjadi warisan budaya Indonesia ataupun warisan budaya Unesco seperti yang telah dilakukan untuk angklung di Bandung. Adanya pengakuan dari Indonesia maupun Unesco akan meminimalkan adanya duplikasi kesenian sejenis yang dapat diakui oleh daerah maupun Negara lain, sehingga kelestarian gamelan jegog dapat dinikmati oleh masyarakat Kabupaten Jembrana, Indonesia, dan dunia.

(2) Penetapan standarisasi pementasan

Standarisasi pementasan adalah perlunya peningkatan kualitas pertunjukan kesenian tanpa mengurangi nilai-nilai budaya yang ada. gamelan jegog harus menetapkan standar yang tepat dalam setiap pementasan, sehingga dapat mempengaruhi harga yang dibayarkan oleh wisatawan. Adanya standarisasi tersebut, menjamin setiap pementasan gamelan jegog difasilitasi dengan baik oleh pihak penyelenggara yang hendak menggunakan jasa dari gamelan jegog. 


\subsection{Strategi WT (weaknesses-treath)}

Merupakan strategi yang meminimalkan kelemahan dan menghindari ancaman, diimplementasikan sebagai berikut.

(1) Memperkuat branding terhadap kesenian gamelan jegog

Pemberian branding merupakan suatu upaya yang dapat dilakukan Gamelan jegog untuk menarik wisatawan. Meskipun dengan lokasi yang jauh dari bandara dan pusat pariwisata Bali, dengan penggunaan branding yang tepat dapat menarik minat wisatawan untuk menikmati gamelan jegog. Branding yang dibuat haruslah bersifat perwakilan dari apa yang sebenarnya ada pada gamelan jegog, membuat penasaran, dan juga gampang untuk diingat baik dalam penggunaan kata maupun penggunaan gambar-gambar. Dengan branding inilah masyarakat, Pemerintah Kabupaten Jembrana dan juga Provinsi Bali dapat mempromosikan gamelan jegog pada setiap event promosi yang diikutinya.

(2) Melakukan pembenahan sumber daya alam dan sumber daya manusia

Kurangnya sumber daya alam di Kabupaten Jembrana dan juga kualitas pementasan gamelan jegog harus disikapi dengan melakukan pembenahan. Harus diadakan latihan terus-menerus guna meningkatkan kualitas penampilan kesenian gamelan jegog. Ketersedian sumber daya alam yang semakin berkurang harus disikapi dengan cara melakukan pembibitan maupun penanaman pohon bambu dengan tujuan tersedianya bahan utama pembuatan gamelan jegog. Pelatihan-pelatihan pementasan dan pembinaan gererasi muda supaya dapat melanjutkan kesenian gamelan jegog, sehingga gamelan jegog akan tetap lestari dan dapat meningkatkan kualitas pementasanya.

\section{Penutup}

Gamelan jegog Suar Agung sebagai daya tarik wisata di Kabupaten Jembrana masih belum optimal, sehingga perlu digali potensi yang ada sehingga dapat dikembangankan, namun tidak terlepas juga kendala yang harus diidentifikasi sehingga dapat diminimalkan masalah dalam pengembangannya. Gamelan jegog memiliki potensi yang layak untuk dikembangkan dengan menggali setiap atraksi yang dimiliki gamelan jegog. Kemudahan akses, layanan penunjang dan juga kelembagaan yang jelas akan memudahkan wisatawan untuk dapat mengakses dan mengetahui keberadaan gamelan jegog. Keinginan wisatawan akan semakin bertambah untuk dapat menikmati pementasan gamelan jegog. Pengembangan gamelan jegog kedepan tentunya akan lebih baik dengan cara meminimalkan kendala fisik, kendala sumber daya manusia maupun kendala lainnya yang menjadi kendala utama dalam pengembangan gamelan jegog.

Strategi pengembangan gamelan jegog Kabupaten Jembrana adalah sebagai berikut. Strategi SO (strength-opportunities) yaitu dengan 
pengembangan potensi wisata di Kabupaten Jembrana dan meningkatkan kerjasama dan pemanfaatan teknologi. Pengembangan potensi di Kabupaten Jembrana dan pemanfaatan kemajuan teknologi sebagai media promosi akan menjadi strategi yang tepat untuk mengembangkan gamelan jegog di Kabupaten Jembrana.

Strategi SWOT bagi pengembangan gamelan jegog di Kabupaten Jembrana dapat dibagi menjadi tiga strategi alternative. Adapaun beberapa strategi yang dapat diterapkan antara lain: Strategi WO (weaknessesopportunities) dengan cara penggalian dana dalam pengembangan gamelan jegog dan memaksimalkan peran serta pemerintah Provinsi Bali dalam promosi gamelan jegog. Strategi ST (strength-threats) dapat dilakukan dengan alternatif strategi yaitu penetapan Gamelan Jegog sebagai warisan budaya Indonesia dan penetapan standarisasi pementasan. Strategi WT (weaknesses-threats) memperkuat branding terhadap kesenian jegog serta melakukan pembenahan sumber daya alam dan sumber daya manusia.

\section{Ucapan Terima Kasih}

Pada kesempatan ini perkenankanlah penulis mengucapkan terimakasih yang sebesar-besarnya kepada Prof. Dr. N.L. Sutjiati Beratha, M.A. dan Dr. I Nyoman Madiun, M.Sc. selaku pembimbing I dan II tesis yang dengan penuh kesabaran telah memberikan bimbingan dan saran kepada penulis selama penyelesaian tesis dan penulisan artikel ini. Ucapan terimakasih yang sebesar-besarnya juga disampaikan kepada anggota penguji; Prof. Dr. I Nyoman Darma Putra, M.Litt. Prof. Dr. I Nyoman Kutha Ratna, SU. dan Dr. Ir. I Made Adhika, MSP atas bimbingan, saran sanggahan, koreksi, dan masukan, sehingga tesis ini dapat terselesaikan, para dosen dan staf administrasi Kajian Pariwisata atas segala bantuannya dalam memperlancar proses perkuliahan

\section{Daftar Pustaka}

Paturusi, Syamsul Alam. 2008. Perencanaan Kawasan Pariwisata. Denpasar : Press UNUD

Rangkuti, Freddy. 2001. Analisis SWOT: Tekhnik Membelah Kasus Bisnis: Reorientasi Konsep Perencanaan Strategi Untuk Menghadapi Abad 21. Jakarta: Gramedia Pustaka Utama.

Subagyo, Joko. 2006. Metode Penelitian Dalam Teori dan Praktek. Jakarta: RINEKA CIPTA.

Sugiarto, Endar dan Kusmayadi. 2000. Metode Penelitian Dalam Bidang Kepariwisataan. Jakarta: Gramedia Pustaka Utama.

Suwena, I Ketut. 2010. Pengetahuan Dasar Ilmu Pariwisata. Denpasar: Udayana

University Press.

Undang-Undang No.10 Tahun 2009. Tentang Kepariwisataan. Jakarta. Kementerian 
Kebudayaan dan Pariwisata.

Yoeti, Oka A, 1997. Perencanaan dan Pengembangan Pariwisata. Jakarta: PT. Pradnya Paramita.

Yoeti, Oka A. 2006. Tour and Travel Marketing, cetakan kedua. Jakarta: PT. Pradnya Paramitha.

\section{Profil Penulis}

I Komang Edy Wirawan menyelesaikan Program Studi S-2 Kajian Pariwisata Universitas Udayana tahun 2016. Tahun 2013 menyelesaikan kuliah Diploma Empat (DIV) di Sekolah Tinggi Pariwisata Nusa Dua Bali (STPND) dan jurusan yang diambil adalah Manajemen Kepariwisataan dengan gelar Sarjana Sains Terapan Pariwisata (SST.Par). Pada tahun 2015 bekerja di Lingkungan Pemerintah Kabupaten Karangasem pada Dinas Kebudayaan dan Pariwisata.

Prof. Dr. Ni Luh Sutjiati Berata adalah dosen prodi Magister Kajian Pariwisata, dosen Prodi Sastra Inggris Fakultas Ilmu Budaya (FIB) Universitas Udayana. Sejak tahun 2015, beliau menjadi Dekan FIB Unud. Bersama I wayan Ardika dan I Nyoman Dhana, beliau menulis buku Dari Tatapan Mata Ke Pelaminan Sampai di Desa Pakraman: Studi tentang Hubungan antara Orang Bali dengan Orang Cina di Bali (2010, Udayan University Press). Minat penelitiannya adalah bidang linguistik, linguistik budaya, dan seni dan kebudayaan Bali. Email: sutjiati59@gmail.com 